\title{
WHAT THE FOOD MANUFACTURER THINKS OF S. 1944
}

\author{
LAURENCE V. BURTON*
}

If the food manufacturer could be sure that he could attain perfection in mindreading and in forecasting the thoughts that might sometime arise in the bureaucratic mind, his opposition to this attempt at regulatory legislation might be lessened. As it is, however, he is taking no chances and is doing his utmost to defeat it.

Ever since March 4, a marked change has come over the administrative philosophy of the United States, as far as it can be determined by a study of current events and current as well as pending legislation. The proposed revision of the Food and Drug Act, Senate Bill 1944, has been born of the same philosophic concept that gave birth to the other New Deal legislation. Indeed, on November 7, 1933, Mr. W. R. M. Wharton, chief of the eastern food and drug inspection district of the Food and Drug Administration, gave a radio broadcast in which he specifically stated that S. I944 was an integral part of the New Deal.

Like all the rest of the New Deal activities, this bill is based on an idealistic concept, a concept which merits the support of all right-thinking manufacturers as well as the consuming population. The concept, well stated in the title of the Bill, is "To prevent the manufacture, shipment, and sale of adulterated or misbranded foods, drugs and cosmetics, and to regulate traffic therein; to prevent the false advertisement of food, drugs and cosmetics. ..."

Like most of the New Deal legislation, the philosophy underlying this concept seems to be that the American public is incapable of governing itself any more, that it needs to be saved from itself by the guidance of a group of youthful economists, amateurs in the field of statecraft, who as yet seem to have failed to recognize that most statutes inevitably entail an economic reaction, and that economic reactions are almost always followed by political reactions. Political reaction, as used here, refers to the reaction of a group of citizens toward the government, and is not used in the popular sense which regards politics as the art of winning elections.

It is unfortunate that this important piece of pending legislation lacks a true understanding of the reaction that must needs follow a crusade, however worthy

* B.S. (Chemical Engineering), M.S. (Biological Chemistry), University of Illinois; Ph.D. (Bacteriology), Yale University. For nearly twenty years associated with food manufacturing concerns prior to his first connection with Food Industries, a leading journal of the food industries, of which he is now the editor. 
may be its objective. There are no decent food manufacturers, of the scores which have been consulted, who take exception to the obvious intent of the bill. Many have exclaimed that it is high time something was done about some of the current unethical and absurd or highly objectionable practices that exist in the food, drug and cosmetic industries today.

In the field of food manufacture it is recognized that, of the evils at which this bill is directed, some are causes of the uneconomic conditions prevailing in the competition for a place on the American dinner-table.

The food manufacturers agree that the objective of S. I944 is a worthy one (unfortunately I cannot speak for drug and cosmetic manufacturers, because of unfamiliarity with their field), and furthermore they agree that the bill will without question enable the Food and Drug Administration to accomplish exactly what it has set out to do.

Further examination of the bill shows them that it does not stop at the point of elimination of evil practices-far from it. The bill is so broadly drawn that any manufacturer can read into it a multitude of distinct perils for the very existence of his own business. He believes these perils are very real, despite the fact that this legislation is not directed at him at all, and despite all assurances from its authors or from the Food and Drug Administration that they have not the slightest intention of interfering with the conduct of his affairs as long as he pursues his current policies.

His fear is based on the fact that the interpretations of the powers granted to the Secretary of Agriculture are not restricted in any way. Too much of the bill is worded in such a way that the regulations thus created are not to be found in the bill but will be found later in the minds of the successive Secretaries of Agriculture and the successive enforcement officers to whom certain powers must be delegated.

Some of these fears would never have come to light had not one of the authors of the bill, the Assistant Secretary of Agriculture, Professor R. G. Tugwell, revealed so much of his economic philosophy in various publications and public utterances. The world knows that he has visited Russia and has found its institutions acceptable, that apparently he believes that packaging and advertising constitute economic waste that should be prevented.

One should not discuss here the merits of those beliefs which are imputed to him, but we must face the inescapable fact that this bill is the creation of the minds of a few men, of which his is the most influential. And we must further face the fact that this bill apparently creates sufficiently broad powers so that his economic philosophy may be imposed on the food industries whether it is necessary or not.

The inevitable result of this fear is a growing opposition on the part of those who might conceivably be benefitted by the elimination of some of the practices which this bill seeks to stop. No food manufacturer will accept this piece of legislation, no matter how little it will apparently affect him, without the most vigorous opposition 
that he can put up. And the reasons for his opposition are manifold, but primarily they are based on the principle that the exact meaning of many important sections of the bill are largely a matter of official interpretation by individuals. The manufacturer is not losing sight of the expense of law suits. Regarding litigation in the light of the long-standing belief that "if you win you lose," in this day of need for rigid economy no manufacturer willingly incurs the cost, even of a trip to Washington, to attend a hearing let alone entering a court action, unless it is unavoidable.

The fault that is found with this bill is not in its intent, but in its drafting. Through failure of the drafters to foresee the succession of reactions that are inevitable, the feeling is growing that it is far better to discard the whole measure than to allow it to go on the statute books containing such phrases as "if by ambiguity or inference it creates a misleading impression." The bill itself, as well as the propaganda now being conducted by the government, is open to the charge of ambiguity and inference.

To confer such drastic and absolute powers, as are conveyed under the permit section, that the Secretary of Agriculture has the power of life or death over a business, where only he has the right to adjudge the situation, is repellent to every manufacturer. If the authors of that section contemplate only supervision of the traffic in shellfish and/or milk, or those foods which may be a potential health hazard by reason of their frequent consumption in uncooked condition, by all means let that legislation be specified in the bill. It is then possible to consider the merits of that proposed section of the bill without the hampering effect of fearful prejudices which are bound to arise out of its present all-inclusive breadth.

To many executives in industry there is little doubt that their own foresight has been developed through constant exercise and has been tested by trial and error to a far greater extent than that of the inexpert, though earnest, zealots. The defensive reactions of the executive mind are therefor immediately aroused by many features of the bill such as the definition that adulteration occurs "if any valuable constituent has been in whole or in part abstracted" from a food. Although any well-informed person realizes that such a definition is aimed at the prevention of deception or fraud, many a food manufacturer realizes at once that the intent to deceive or defraud need not be shown by the government in order to make a successful prosecution. And as a result the flour miller can see in this clause a possible mandate to mill only whole wheat flour in case a whole-wheat faddist should come into power in the enforcement of the bill.

The canner foresees very definite harassing problems arising out of the use of the word "classes" in Section 6 dealing with misbranding. With the recent experiences and difficulties under the McNary-Mapes Amendment to the existing law, they should not be stigmatized as reactionary if they balk at this provision, as well as the provision that quality grades must be declared correctly on the label.

Another place where all manufacturers balk is on Section 13 which permits 
government inspectors to examine "methods and processes" as well as the rest of the premises of a plant. No doubt these words mean one thing to the drafters of the bill, but to the manufacturer this means something else-the disclosure of formulas and any technical secrets irrespective of their relation to the stated intent of the bill.

And when he is required constructively to publish his formula under the provisions of Section $7(f)$ his exasperation is entirely justifiable. Indeed, there seems to be hidden in the whole bill a distinct hostility to specialty or proprietary foods. One can understand the good purposes of some provisions of the bill, but in Section $7(f)$ there is not discernible at this time any real improvements to be attained in its application to food over the provisions of the present law.

Many costly practical difficulties will arise from Section $7(f)$. The ratio of various ingredients of many manufactured foods will vary with their relative costs, all of which will necessitate a manufacturer to have on hand a great variety of labels differing only in the relative position of wording of ingredients, if he is to be able to comply with this provision. It will double and sometimes triple the size of label inventories in certain lines of manufacture, and when it is realized that label inventories commonly run as high as $\$ 50,000$ to $\$ 100,000$ in large plants, it is realized that here is an unnecessary waste that should be avoided.

A ridiculous situation also arises under Section $7(f)$ when assorted packaged foods, e.g., assorted chocolate candies, are labeled in compliance with its requirements. The top of a one-pound box of assorted chocolates is usually not large enough to carry all of the data required. Even the problem of correct labeling of a single piece such as an "O HENRY" candy bar is so overwhelming that one wonders what has become of the common sense of the drafters of the bill. Did they fail to discuss the practicability of this clause with any manufacturer?

These drafters have erroneously reasoned from the experience of Bureau of Animal Industry inspection service, that the Bureau of Food and Drug inspection could set up a system of voluntary inspection that would be avidly embraced by all food manufacturers, forgetting that the Bureau of Animal Industry inspector is largely employed as a pathologist for the inspection of carcasses for diseased animals. His job is really an integral part of the well organized production line. He performs a service that is useful to the meat packer as well as a service that is very beneficial to the public. But where, pray, can we find a parallel place for his services in other lines of manufacture?

If the food manufacture is aware of the real implication of Section 24, "A right of action for damages shall accrue to any person for injury or death proximately caused by violation of this act," he will oppose it or the whole bill even to its ultimate destruction. The opposition here arises from the fact that it opens the door wide to the ambulance chaser, be he lawyer or physician. It can make any violation of the law, however trivial, the basis of an attempt to collect easy money through its failure to distinguish between offenses which are malum prohibitum and malum per se. 
Opinions have already been expressed that this section could easily break a hapless food manufacturer through the cost of defending fake damage suits which might be based on convictions where the offense is only malum prohibitum. There is, of course, no likelihood of evasion of responsibility where the offense is characterizable as malum per se. It seems advisable, however, in the interest of sound progress that the inhibitory character of this section be recognized and modified.

Whether the food manufacturer will sign up for voluntary inspection in case the bill becomes law is impossible to determine at this time. It will be necessary for the manufacturer to first ascertain just how much responsibility the government will accept in his plant.

The strangest anomaly in the bill is the complete absence of any provision to correct a serious problem of twenty-seven years' standing. The Bureau of Food and Drug Inspection has never granted an approval for an acceptable label, but has always reserved the right to prosecute for misbranding the hapless individual who has failed to guess rightly what the bureau really requires. Such extreme conservatism has no place in a bill of so radical a character. And to a manufacturer of long experience this defect of omission is amusing, to state it mildly.

The provision to prevent false advertising, however good its intent, is so worded that no manufacturer will lend his support to the measure. When it is not denied that under the phraseology of their bill it will be possible to jail a man for a year for such an innocuous statement in an advertisement as "Let Santa Claus bring you Blank's Chocolates for Christmas," or to inflict a similar penalty on a maker of carbonated beverages because his advertising may suggest that Eskimos have something to do with his product, it is high time to call a halt. The zeal for reform has gone to absurd limits. And when one learns that the real intent of the perpetrators of such legislative nonsense was to rush this bill through Congress as emergency legislation, in the special session in 1933, it is understandable why the clauses pertaining to advertising were so clumsily drawn. It takes more time to draft legislation which will merit our moral approval than was evidently possible to devote to this bill in the great haste in the Spring of 1933. The too all-inclusive features of Sections 9 and $x 7$, particularly the admittedly pernicious implication of Section 17 (d), deserve the severest censure. Professor Tugwell's reputed belief that advertising is economic waste is apparently hard at work in this connection.

No manufacturer of foods opposes regulation of advertising which has for its intent, the purpose of defrauding the public. If the government's exhibit, popularly known as the Chamber of Horrors, is an index of the advertising which it hopes to prevent, then why in the name of common sense does not this bill more accurately describe the offense?

As long as this bit of legislation is pending, al. kinds of manufacturers of both good and bad character are united in opposition to it, and the good manufacturer will not relent until it is plainly discernible, by even a business man, that he cannot be penalized by a fanatical interpretation of this bill. 
The opposition to this bill is not an effort to perpetuate a status quo of liberty to continue to do the harmful things that the bill seeks to avoid. Rather it is an effort to avoid the multiplicity of absurdities and injustices that the bill would create.

Within the space limitations of this article it is impossible to discuss or even enumerate all of the objectionable features of S. 1944. The best that can be said for it is that it is a very inexpert attempt to attain a worthy end. It should be withdrawn and redrafted with greater deliberation and with the advice of the several industries to come under its jurisdiction. 